\title{
INTRODUKSI TEKNOLOGI MEKANIS PADA USAHA BUDIDAYA DAN OLAHAN JAMUR TIRAM DI 2 UKM KOTA BATU
}

\author{
Mechanical Technology Introduction to Two Small Medium Entreprises of Oyster Mushroom \\ Cultivation and Processing at Batu Regency
}

\author{
Jaya Mahar Maligan ${ }^{1)}$ dan Edyson ${ }^{2)}$ \\ Jurusan Teknologi Hasil Pertanian, FTP Universitas Brawijaya ${ }^{1)}$ \\ Jl. Veteran, Malang 65145 \\ Fakultas Pertanian, Universitas Tribhuwana Tunggadewi ${ }^{2)}$ \\ Jl. Tlagawarna, Malang 65144
}

\begin{abstract}
This community service program aimed to introduce mechanical technology in the process of baglog filling efficiency on SMEs Indie Mushrooms and efficiency of liquid batter (batter) and coating flour, and also flavoring mushroom processing technology on SMEs Agronusa Mushroom. In addition, socialization Good Agriculture Practice (GAP) on mushroom cultivation in SMEs Indie Mushrooms and Good Manufacturing Practices (GMP) on the processing of white oyster mushroom based products in the SME Agronusa Mushroom were conducted. By transferring technology through the introduction of mechanical baglog filling machine in SMEs Indie Mushrooms, increasing efficiency of baglog filling occurred. After the IbM activity, baglog preparation process can be accelerated to 1-2 days. Mechanical technology transfer is also applied to SMEs Agronusa Mushroom by introducing kneading machines, mixers and freezer for production of spring rolls, risoles, and oyster mushroom chips. Efficiency of flour stirring and coating increased to 20 minutes, while stirring batter increased to 15 minutes. Socialization and mentoring of GAP and GMP have also been carried out on both partners.
\end{abstract}

Keywords: SMEs, oyster mushroom, introduction of technology

\begin{abstract}
ABSTRAK
Program pengabdian masyarakat ini bertujuan untuk mengintroduksikan teknologi mekanis dalam proses efisiensi pengisian baglog pada UKM Indie Jamur dan efisiensi pembuatan adonan cair (batter) dan tepung serta teknologi pengolahan penyedap rasa jamur pada UKM Agronusa Mushroom. Selain itu dilakukan sosialisasi Good Agriculture Practise (GAP) pada budidaya jamur di UKM Indie Jamur dan Good Manufacturing Practices (GMP) pada proses pengolahan produk berbasis jamur tiram putih di UKM Agronusa Mushroom. Dengan adanya alih teknologi mekanis pengisian baglog dengan introduksi mesin pengisi baglog di UKM Indie Jamur, terjadi peningkatan efisiensi waktu pengisian baglog. Setelah kegiatan IbM proses persiapan baglog bisa dipercepat menjadi 1-2 hari. Selain itu, alih teknologi mekanis juga diaplikasikan pada UKM Agronusa Mushroom yaitu dengan introduksi mesin pengaduk adonan, mixer dan penambahan freezer untuk produksi lumpia, risoles, dan keripik jamur tiram. Efisiensi pengadukan tepung dan penyalutan jamur meningkat menjadi 20 menit, sedangkan pengadukan batter meningkat menjadi 15 menit. Sosialisasi dan pendampingan GAP dan GMP juga telah dilaksanakan pada kedua mitra.
\end{abstract}

Kata kunci: UKM, jamur tiram putih, introduksi teknologi 


\section{PENDAHULUAN}

Jamur tiram merupakan bahan makanan bernutrisi dengan kandungan protein tinggi, kaya vitamin dan mineral, rendah karbohidrat, lemak, dan kalori. Jamur tiram juga dipercaya mempunyai khasiat obat untuk berbagai penyakit, seperti lever, diabetes, anemia, sebagai antiviral, dan antikanker (Kurnianingsih, 2008), menurunkan kadar kolesterol (Hossain et al., 2003), dan mempunyai aktivitas sebagai penangkap radikal bebas ( $\mathrm{Fu}$ et al., 2002). Olahan jamur tiram (Pleurotus ostreatus) mempunyai citarasa mirip dengan daging ayam karena tekstur berserat serta gurih. Hal ini menyebabkan pasar jamur tiram cukup diminati di masyarakat. Olahan jamur tiram mendapat respon positif bagi para vegetarian dan pelaku diit karena kadar serat dan rasanya yang mirip daging. Hal ini yang mendorong Bapak Joni Rahmat melakukan usaha olahan jamur tiram dengan nama UKM Agronusa Mushroom. Usaha olahan jamur tiram ini terletak di Dusun Wonorejo, Desa Tulungrejo, Kecamatan Bumiaji, Kota Batu. Di Desa Tulungrejo terdapat 30 petani yang membudidayakan jamur tiram yang tergabung dalam kelompok tani Agro Adi Jaya.

Bapak Joni sendiri juga membudidayakan jamur tiram dengan tujuan utama memenuhi kebutuhan bahan baku untuk produk olahannya berupa bakso jamur, lumpia jamur, risoles jamur, tahu jamur, martabak jamur, nuget jamur, dan keripik jamur/jamur crispy. Produk olahan tersebut dipasarkan dalam bentuk beku (frozen food) dan dijual tanpa label dan kemasan (dijual curah). Pembeli biasanya melakukan pengemasan untuk produk tersebut dan menggunakan label sendiri. Dalam satu hari, produksi risoles dan lumpia mencapai 600-700 buah yang dijual seharga Rp. 2000/buah untuk risoles dan Rp. 1500/buah untuk lumpia. Kedua produk ini merupakan produk unggulan karena pesaing yang masih sedikit. Produk lain yang banyak peminatnya adalah jamur crispy. Dalam 1 hari produksi, UKM Agronusa
Mushroom membutuhkan 40-50 kg jamur tiram segar. Jumlah ini tidak bisa dipenuhi dari hasil budidaya jamur sendiri. Oleh karena itu, UKM Agronusa Mushroom membeli jamur tiram dari petani lain di Desa Tulungrejo yang tergabung dalam Kelompok Tani Agro Adi Jaya. Salah satu pemasok jamur tiram segar ke UKM Agronusa Mushroom adalah Bapak Purnomo dari UKM Indie Jamur. Setiap hari UKM Indie Jamur memasok 50-60 kg jamur tiram ke UKM Agronusa Mushroom.

Proses produksi jamur tiram di UKM Indie Jamur dapat dilihat pada Gambar 1. Media budidaya jamur adalah serbuk gergaji, bekatul, kalsium karbonat, dan tepung jagung yang diaduk rata. Pengadukan telah dilakukan menggunakan mesin pengaduk. Media kemudian dimasukkan ke dalam baglog secara manual. Proses pengisian baglog ini cukup memakan waktu karena dalam 1 hari hanya bisa dilakukan pengisian 120-200 baglog karena baglog setelah terisi harus dimampatkan. Mitra 1 (UKM Indie Jamur) menyampaikan bahwa proses ini merupakan bottle neck produksi jamur tiram karena untuk mempersiapkan 1000 baglog dalam 1 kali musim tanam, diperlukan waktu pengisian 5-8 hari. Selanjutnya baglog yang sudah terisi ditutup rapat dan disterilisasi menggunakan sterilizer dari drum. Baglog steril kemudian diinokulasi dengan bibit jamur tiram untuk kemudian disusun dalam naungan budidaya jamur. Satu baglog dalam 1 musim tanam bisa dipanen 4-5 kali dengan hasil panen 1 baglog adalah 4 ons jamur segar. Mitra Indie Jamur menghasilkan jamur tiram dalam 1 hari sebanyak $50-60 \mathrm{~kg}$.

Pada proses produksi jamur tiram diperlukan penerapan prinsip-prinsip Good Agriculture Practices (GAP). GAP merupakan pendekatan yang diperlukan untuk menjamin keamanan dari hasil pertanian segar untuk konsumsi. GAP dan panduan penanganan pasca panen diperlukan untuk menekan risiko kontaminasi penyebab food borne disease. 
GAP diterapkan pada sumber-sumber kontaminasi seperti tanah, air, tangan pekerja, dan peralatan.

Jamur tiram yang dihasilkan oleh Mitra 1 dijual ke Mitra 2 Agronusa Mushroom dengan harga Rp. 9000/kg. Kekurangan jamur dari Mitra 1 biasanya dipenuhi oleh Mitra 2 dengan cara membeli dari petani lain tetapi dengan harga yang lebih mahal yaitu Rp. $10.500 / \mathrm{kg}$. Hal ini yang menyebabkan Mitra 2 menjadi Mitra 1 sebagai pemasok tetap jamur tiram segar.

Produk unggulan Mitra 2 adalah risoles dan lumpia jamur dengan produksi per bulan berkisar 18.000-21.000 buah dengan jumlah lumpia $40 \%$ dari total produksi. Produk unggulan lain adalah jamur crispy yang dibekukan dengan produksi per bulan $150 \mathrm{~kg} / \mathrm{bulan}$. Produk lain seperti bakso jamur, tahu jamur, martabak jamur, nugget jamur diproduksi dalam jumlah yang lebih kecil.

Proses pembuatan lumpia dan risoles hampir mirip yaitu pembuatan kulit dari campuran terigu, air, telur, dan bumbu dan dikocok sehingga terbentuk adonan cair (batter). Isi kedua produk adalah jamur yang telah direbus terlebih dahulu kemudian ditumis dengan bumbu. Selanjutnya batter dibuat dadar tipis sebagai bahan pembungkus. Isi jamur dibungkus dengan kulit risoles atau lumpia. Untuk risoles ada tahapan selanjutnya yaitu penyalutan (coating) menggunakan tepung panir atau tepung roti. Pada proses penyalutan ini, dibuat adonan kental sebagai perekat tepung panir. Risoles kemudian dicelupkan ke dalam adonan perekat dan selanjutnya disalut dengan tepung panis. Risoles dan lumpia kemudian digoreng setengah matang dan dibekukan.

Dari hasil diskusi terungkap bahwa kendala yang dihadapi Mitra 2 pada proses produksi risoles dan lumpia ini adalah proses pembuatan adonaan cair (batter) yang membutuhkan waktu lama karena Mitra 2 masih menggunakan hand mixer skala rumah tangga. Satu kali proses pengadukan untuk $2 \mathrm{~kg}$ tepung memerlukan waktu 20 menit sehingga dalam sehari dengan $8 \mathrm{~kg}$ tepung diperlukan waktu 80 menit. Yang menjadi masalah adalah hand mixer tersebut tidak bisa digunakan secara kontinyu karena menjadi panas. Setelah pembuatan adonan cair selesai, hand mixer digunakan kembali untuk membuat adonan kental untuk proses penyalutan tepung panir. Hal ini menyebabkan proses produksi risoles dan lumpia menjadi tidak efisien karena proses pembuatan adonan yang lama.

Masalah lain yang dihadapi Mitra 2 adalah pencampuran tepung untuk penyalut jamur crispy yang masih manual menggunakan pengaduk. Proses pengolahan jamur crispy dapat dilihat pada Gambar 2. Mitra memproduksi jamur crispy $150 \mathrm{~kg}$ per bulan dan dalam $1 \mathrm{kali}$ produksi jamur tiram yang diolah adalah 20 $\mathrm{kg}$ dengan jumlah tepung $10 \mathrm{~kg}$. Tepung tersebut merupakan campuran berbagai bahan seperti bumbu, terigu, tepung beras, maizena. Dalam satu kali proses mitra harus mengaduk $10 \mathrm{~kg}$ tepung secara manual. Mitra menginginkan adanya mesin pengaduk yang dapat digunakan untuk mengaduk tepung dan proses penyalutan jamur tiram dengan tepung penyalut.

Pada proses pengolahan beberapa produk jamur tiram beku seperti bakso, nugget, martabak, lumpia dan risoles, jamur tiram direbus terlebih dahulu. Pada proses perebusan tersebut, air sisa rebusan jamur tiram banyak dihasilkan. Rasa air rebusan ini gurih tetapi mitra belum bisa memanfaatkan air perebusan jamur tiram menjadi produk yang bernilai ekonomi. Air perebusan jamur tiram dapat dimanfaatkan sebagai bahan baku penyedap rasa (flavor enhancer) dari jamur. Produk tersebut telah ada di pasaran, tetapi masih merupakan produk impor terutama dari Cina. Introduksi teknologi pengolahan penyedap rasa dari jamur tiram (omfe, oyster mushroom flavor enhancer) menjadi penting bagi Mitra 1 untuk meningkatkan nilai ekonomi air rebusan jamur tiram.

Dari hasil uraian sebelumnya, dapat disimpulkan bahwa masalah yang dihadapi Mitra 1 UKM Indie Jamur adalah efisiensi pengisian baglog dan GAP yang belum 
sepenuhnya diterapkan. Masalah yang dihadapi Mitra 2 adalah efisiensi pembuatan adonan cair (batter) dan tepung yang masih rendah, serta air perebusan jamur tiram yang belum dimanfaatkan dan berpotensi untuk diolah manjdi penyedap rasa. Dari kesepakatan dengan mitra, program untuk mengatasi permasalah di kedua mitra adalah mekanisasi pengisian baglog, implementasi GAP, alih teknologi mixing untuk batter dan tepung (dry mixing), serta introduksi teknologi pengolahan penyedap rasa (flavor enhancer) berbasis jamur tiram.

\section{METODE PELAKSANAAN}

Pelaksanaan kegiatan IbM ini ditujukan untuk memecahkan permasalahan yang dihadapi oleh UKM Indie Jamur dan UKM Agronusa Mushroom. Metode pelaksanaannya adalah sebagai berikut:

\section{a) Peningkatan efisiensi pengisian baglog di Mitra 1 UKM Indie Jamur}

Peningkatan efisiensi pengisian baglog diperlukan untuk mempersingkat waktu pengisian baglog yaitu 5-8 hari untuk 1000 baglog. Penggunaan mesin pengisi baglog diperlukan untuk mengatasi masalah tersebut. Mekanisasi pengisian baglog diharapkan dapat memparsingkat waktu pengisian dari 5-8 hari untuk 1000 baglog menjadi 100-200 menit, karena mesin pengisi baglog mempunyai kapasitas 6-10 baglog/menit. Harapannya waktu yang dibutuhkan mitra untuk menyiapkan 1000 baglog untuk 1 kali musim tanam menjadi lebih singkat dari 10 hari menjadi 3 hari. Hal ini akan meningkatkan produktivitas Mitra 1 dalam memproduksi jamur tiram dari 1000 baglog/10 hari menjadi 1000 baglog/3 hari.

\section{b) Implementasi Good Agriculture Practices (GAP) di UKM Indie Jamur}

Mitra 1 perlu diberi penjelasan tentang GAP dalam produksi jamur tiram karena selama ini proses produksi jamur tiram berjalan apa adanya tanpa memperhatikan kemungkinan risiko kontaminasi. GAP perlu diterapkan mulai dari persiapan media tanam atau baglog, pembuatan baglog, pemanenan jamur tiram, dan penanganan pasca panen jamur tiram.

c) Peningkatan efisiensi dan kapasitas produksi lumpia dan risoles jamur di UKM Agronusa Mushroom

Pada proses pembuatan kulit lumpia dan risoles, mitra harus menyiapkan adonan kulit dengan berat tepung terigu $8 \mathrm{~kg} / \mathrm{hari}$. Proses pembuatan adonan cair (batter) tersebut membutuhkan waktu sekitar 2 jam (satu kali proses 20 menit untuk $2 \mathrm{~kg}$ tepung sehingga diperlukan 80 menit untuk $8 \mathrm{~kg}$ tepung, dengan waktu jeda diperlukan total waktu 2 jam). Hal ini menyebabkan kapasitas produksi Mitra 2 per hari untuk produksi lumpia dan risoles jamur menjadi 600-700 buah. Proses pengadukan (mixing) mekanis diperlukan untuk mempersingkat waktu tersebut. Pengadukan juga diperlukan untuk pembuatan adonan perekat pada proses penyalutan risoles dengan tepung panir.

Planetary mixer untuk pengadukan adonan kulit lumpia dan risoles mempunyai kapasitas $8 \mathrm{~kg}$ cream atau batter. Mitra membuat adonan batter kulit lumpia/risoles dengan komposisi $2 \mathrm{~kg}$ terigu ditambah 2,5 $\mathrm{L}$ air dan telur. Artinya dengan menggunakan alat ini, mitra memerlukan 2 proses pengadukan adonan kulit lumpia masing-masing 10 menit sehingga waktu proses berkurang dari 2 jam menjadi 20 menit. Peningkatan efisiensi pengadukan batter pada proses pembuatan kulit lumpia dan risoles diharapkan dapat meningkatkan kapasitas produksi lumpia dan risoles jamur di Mitra 2.

\section{d) Peningkatan efisiensi dan kapasitas produksi jamur crispy di UKM Agronusa Mushroom}

Pada proses pengolahan jamur crispy, jamur tiram yang sudah disuwir-suwir dan direbus diperas sehingga airnya berkurang. Selanjutnya jamur dicelupkan pada adonan perekat kemudian dibalurkan pada adonan 
tepung penyalut. Proses pembuatan tepung penyalut dilakukan dengan cara mencampur bahan-bahan kering (dry mixing) kemudian jamur tiram yang sudah dicelupkan ke perekat disalut dengan tepung dan digoreng. Pada proses pengadukan tepung (dry mixing), dalam 1 hari dilakukan pengadukan $10 \mathrm{~kg}$ bahan yang memerlukan waktu 1 jam. Demikian pula pada proses penyalutan jamur tiram yang sudah disuwir, dibutuhkan waktu 1 jam sehingga proses penyalutan jamur crispy menjadi 2 jam. Alih teknologi mekanis pengaduk kering (dry mixing) diperlukan untuk mempersingkat proses penyalutan jamur crispy.

Mesin pengaduk mekanis digunakan untuk pencampuran kering tepung penyalut dan penyalutan jamur tiram suwir dengan tepung penyalut. Dengan kapasitas 25 $\mathrm{kg} /$ batch (20-57detik) maka proses penyalutan jamur crispy dapat dipersingkat menjadi 5 menit untuk pengadukan tepung, dan 5 menit untuk penyalutan. Oleh karena itu adanya alih teknologi penyalutan jamur tiram pada pembuatan jamur crispy diharapkan dapat meningkatkan kapasitas produksi mitra karena proses penyalutan menjadi lebih singkat dari 2 jam menjadi 10 menit. Artinya Mitra 2 dapat meningkatkan kapasitas produksi jamur crispy sebanyak 35 kali.

Peningkatan kapasitas produksi lumpia, risoles, dan jamur crispy harus disertai dengan peningkatan kapasitas penyimpanan produk akhir. Berhubung produk-produk tersebut merupakan produk beku, maka tempat penyimpanan produk yang sesuai adalah feezer. Pada saat ini mitra sudah mempunyai 2 buah freezer tetapi kapasitas penyimpanan kedua freezer tidak cukup jika terjadi peningkatan kapasitas produksi lumpia, risoles, dan jamur crispy. Oleh karena itu mitra memerlukan peningkatan kapasitas penyimpanan produk bekunya.

e) Diversifikasi produk penyedap rasa berbahan baku air perebusan jamur tiram di Mitra 2

Dalam satu hari produksi Mitra 2 menggunakan $200 \mathrm{~kg}$ jamur tiram segar yang direbus terlebih dahulu sebelum diolah menjadi berbagai produk. Air perebusan jamur tiram berasa gurih dan selama ini belum dimanfaatkan. Jamur tiram merupakan bahan nabati tinggi protein. Rasa gurih dalam jamur tiram berasal dari kandungaan asam amino dalam protein jamur tiram. Asam amino seperti D, L alaninin, $\mathrm{L}$ asparta, dan $\mathrm{L}$ glutamat bersifat gurih dan biasa digunakan untuk bahan flavoring (Fennema, 1996).

Proses pengolahan penyedap rasa jamur menggunakan teknik kristalisasi dengan diagram alir proses dapat dilihat pada Lampiran 2. Teknik ini akan diintroduksikan ke Mitra 2 dan akan dilakukan pendampingan implementasi teknik ini untuk memproduksi penyedap rasa jamur.

\section{HASIL DAN PEMBAHASAN}

\section{a) Peningkatan efisiensi pengisian baglog di Mitra 1 UKM Indie Jamur}

Peningkatan efisiensi pengisian baglog diperlukan untuk mempersingkat waktu pengisian baglog yaitu 5-8 hari untuk 1000 baglog. Penggunaan mesin pengisi baglog diperlukan untuk mengatasi masalah tersebut. Mekanisasi pengisian baglog diharapkan dapat memparsingkat waktu pengisian dari 5-8 hari untuk 1000 baglog menjadi 100-200 menit, karena mesin pengisi baglog mempunyai kapasitas 6-10 baglog/menit. Mesin pengisi baglog saat ini sudah dipesan dan dalam taraf pengerjaan. Pada dasarnya mitra menginginkan mesin pengisi dan sekaligus pengepres baglog. Akan tetapi, unit alat pengisi dan pengepres berharga sangat mahal yaitu $\mathrm{Rp} 40$ juta, Mitra diberi satu pilihan yaitu mesin pengisi baglog atau mesin pengepres baglog. Mitra memilih mesin pengisi baglog karena proses pengisian baglog yang memakan waktu lama. Oleh karena itu, peningkatan efisiensi pengisian baglog belum terjadi. Mesin pengisi baglog telah diterima Mitra 1 pada awal Agustus 2015. 

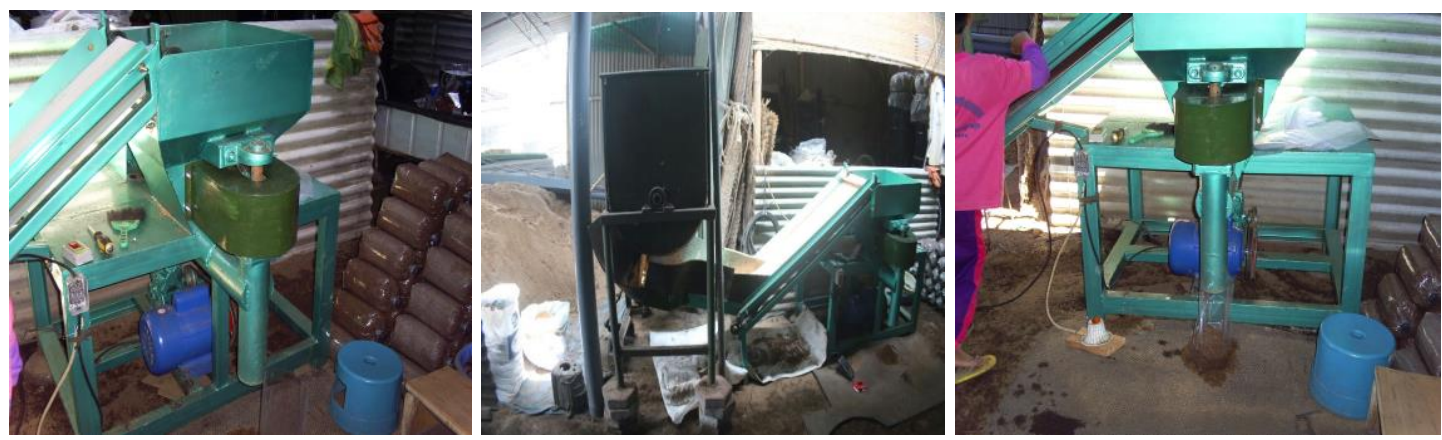

Gambar 1. Mesin pengisi baglog yang diintroduksikan di Mitra 1

Peralatan budidaya jamur tiram yang dimiliki mitra masih sederhana dan sebagain besar dirancang sendiri oleh Bapak Purnomo. Peralatan tersebut dapat dilihat pada Gambar 5 meliputi mesin pengaduk isi baglog serta mesin sterilisasi yang dilengkapi boiler dari drum. Mesin pengisi baglog yang telah diintroduksikan pada Mitra 1 dapat dilihat pada Gambar 1.

Setelah introduksi mesin baglog, Mitra 1 mampu memproduksi 3 baglog per menit, sehingga terjadi efisiensi persiapan 1000 baglog dari sebelumnya 5-6 hari menjadi 12 hari. Target produksi 1000 baglog dalam waktu 100-200 menit belum bisa tercapai karena masih adanya keterbatasan alat, yaitu perlunya peningkatan efisiensi waktu pemindahan bahan campuran baglog menuju konveyor mesin pengisi baglog.

\section{b) Implementasi Good Agriculture Practices (GAP) di Mitra 1.}

GAP tentang budidaya jamur tiram telah disosialisasikan ke Mitra 1. GAP diperlukan supaya budidaya jamur yang dilakukan mitra sesuai dengan cara-cara budidaya pertanian yang baik sehingga hasil produksi jamur tiram yang dihasilkan aman dan bermutu baik.

c) Peningkatan efisiensi dan kapasitas produksi lumpia, risoles, dan keripik jamur di Mitra 2 UKM Agronusa Mushroom

Pada proses pembuatan kulit lumpia dan risoles, mitra harus menyiapkan adonan kulit dengan berat tepung terigu $8 \mathrm{~kg} / \mathrm{hari}$. Proses pembuatan adonan cair (batter) tersebut membutuhkan waktu sekitar 2 jam (satu kali proses 20 menit untuk $2 \mathrm{~kg}$ tepung sehingga diperlukan 80 menit untuk $8 \mathrm{~kg}$ tepung, dengan waktu jeda diperlukan total waktu 2 jam). Hal ini menyebabkan kapasitas produksi Mitra 2 per hari untuk produksi lumpia dan risoles jamur menjadi 600-700 buah. Proses pengadukan (mixing) mekanis diperlukan untuk mempersingkat waktu tersebut. Pengadukan juga diperlukan untuk pembuatan adonan perekat pada proses penyalutan risoles dengan tepung panir.
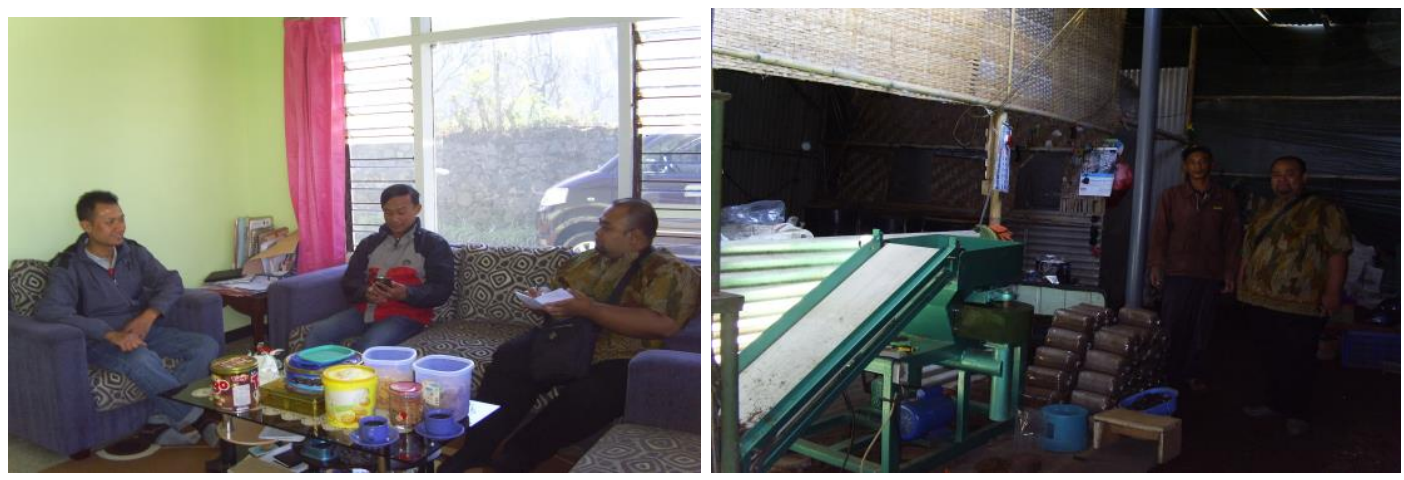

Gambar 2. Sosialisasi Good Agriculture Practice di Mitra 1 
Alih teknologi pengadukan adonan cairan akan dilakukan dengan menggunakan mixer atau pencampur adonan. Setelah kegiatan IbM, proses pengadukan batter hanya memakan waktu selama 20 menit, dari waktu sebelumnya selama 2 jam. Untuk pencampuran kering atau dry mixing, Mitra 2 akan mendapatkan alih teknologi pengaduk tepung kering.

Mesin pengaduk kering atau tepung dapat digunakan untuk pencampuran kering tepung penyalut dan penyalutan jamur tiram suwir dengan tepung penyalut. Adanya alih teknologi penyalutan jamur tiram pada pembuatan jamur crispy diharapkan dapat meningkatkan kapasitas produksi mitra karena proses penyalutan menjadi lebih singkat. Setelah kegiatan IbM, efisiensi pengadukan dan penyalutan jamur menjadi 15 menit, dari waktu sebelumnya yaitu 2 jam. Kegiatan pendampingan mesin pengaduk pada Mitra 2 dapat dilihat pada Gambar 3.

Peningkatan kapasitas produksi lumpia, risoles, dan jamur crispy harus disertai dengan peningkatan kapasitas penyimpanan produk akhir. Berhubung produk-produk tersebut merupakan produk beku, maka tempat penyimpanan produk yang sesuai adalah feezer. Pada saat ini mitra sudah mempunyai 3 buah freezer tetapi kapasitas 1010, 1010 dan 300 L. Saat ini saja prodsuk mitra tidak bisa sepenuhnya dibekukan akibat keterbatasan freezer. Mitra memerlukan peningkatan kapasitas penyimpanan produk bekunya. Freezer dengan kapasitas 330 L juga telah diterima pada bulan Juli 2015. Gambar 5 menunjukkan kegiatan monev internal saat penyerahan freezer di Mitra 2.

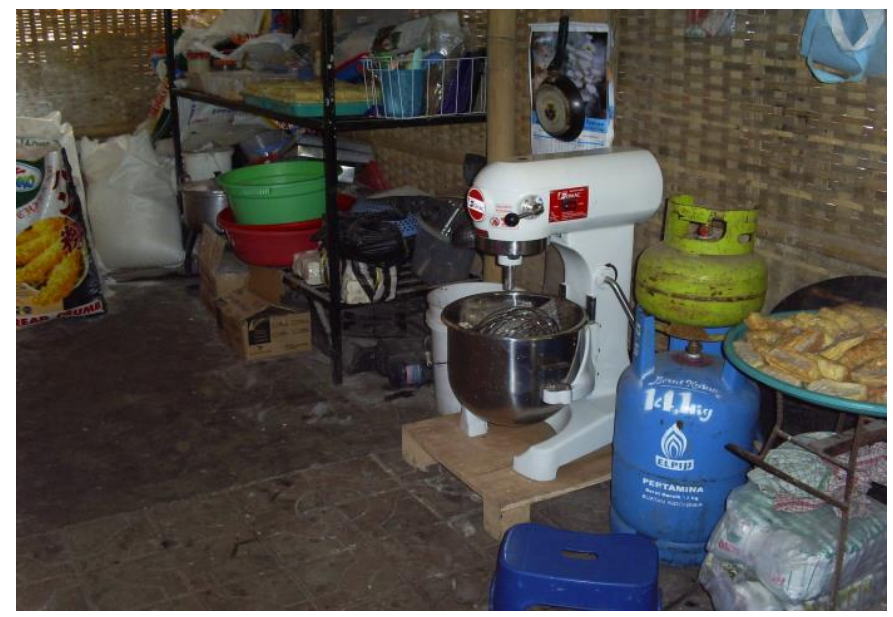

Gambar 3. Planetary mixer untuk pengadukan adonan risoles dan lumpia
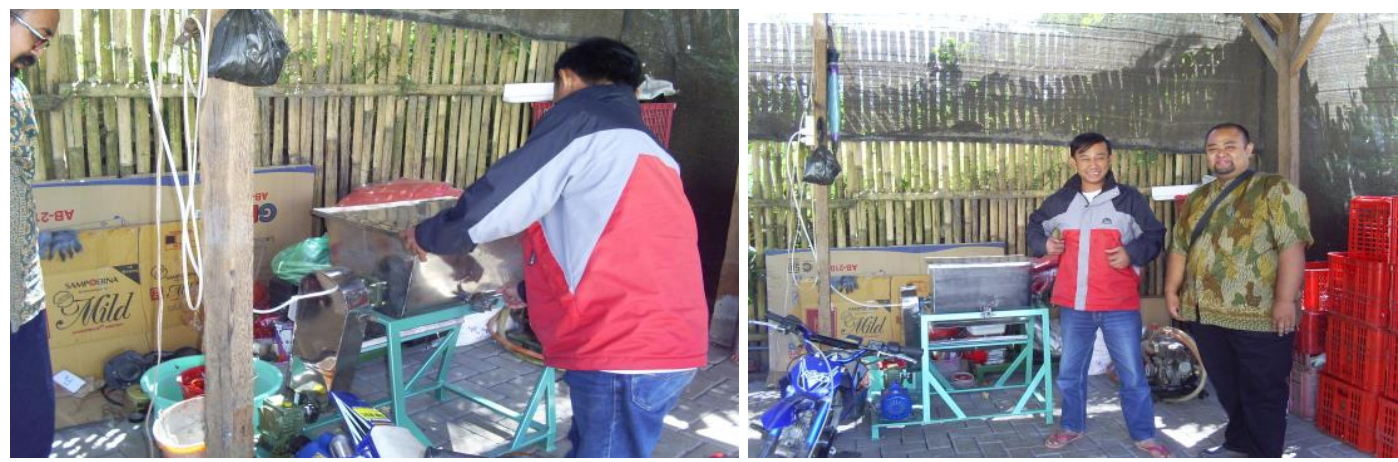

Gambar 4. Pendampingan Penggunaan Mesin Pengaduk di Mitra 2 
Saat ini olahan Mitra 2 telah berkembang, selain lumpia, risoles, dan keripik jamur, Mitra 2 juga memproduksi martabak telur jamur dan tahu bakso jamur. Wilayah pemasaran Mitra 2 adalah Kota Batu, Malang, Surabaya, dan Kalimantan. Pada Bulan Ramadhan seperti ini permintaan produk Mitra 2 meningkat tajam. Hanya saja tidak semua proses atau tahapan produksi produk olahan jamur bisa dimekanisasi seperti pembuatan adonan kulit lumpia, risoles, dan penyalutan risoles dengan tepung panir. Oleh karena itu, usaha mitra bersifat padat karya dan peningkatan produksi di Mitra 2 akan berdampak positif terhadap penyerapan tenaga kerja.

\section{d) Diversifikasi produk penyedap rasa berbahan baku air perebusan jamur tiram di Mitra 2}

Penyedap rasa alami dari air rebusan jamur merupakan salah satu bentuk pemanfaatan air perebusan jamur tiram. Air ini gurih karena kaya asam-asam amino yang bercita rasa gurih. Proses pengolahan penyedap rasa beoum diintroduksikan ke Mitra 2 karena masih menunggu hasil penyempurnaan ujicoba. Pada prinsipnya proses pengolahan penyedap rasa jamur dilakukan dnegan pemekatan dan granulasi menggunakan bahan pengisi. Introduksi teknologi pengolahan penyedap rasa ini akan dilakukan setelah alih teknologi mekanis dilakukan.

Selain introduksi penyedap rasa, Mitra 2 juga perlu diberi pencerahan Good Manufacturing Practices atau CPPB (caracara produksi pangan yang baik). Dari hasil pengaatan $\mathrm{d}$ ruang produksi Mitra 2, tempat produksi olahan jamur tiram belum sepenuhnya sesuai GMP (Gambar 7). Demikian pula dengan sanitasi ruang pengoalhan yang masih belum higienis dan bersih. Hal ini disebabkan Mitra 2 belum mepunyai dana untuk membuat ruang produksi yang layak. Selain sanitasi ruangan, sanitasi pekerja juga belum sepenuhnya bisa diterapkan Mitra 2. Sanitasi pekerja erat kaitannya dengan kebiasaan pekerja seperti kebiasan menggunakan masker, sarung tangan, dan tutup kepala.

Sebenarnya Mitra 2 telah menyadari pentingnya GMP dan GMP wajib yang harus dipenuhi. Hanya saja dalam implementasinya, penerapan GMP membutuhkan pula dana yang cukup. Mitra berkeinginan kuat proses produksinya bisa sesuai GMP karena penerapan GMP akan meningkatkan keamanan produk olahannya serta mutu yang konsisten.

Dari pelaksanaan kegiatan, seluruh luaran hasil kegiatan $\mathrm{IbM}$ ini dapat dilihat pada Tabel 4.
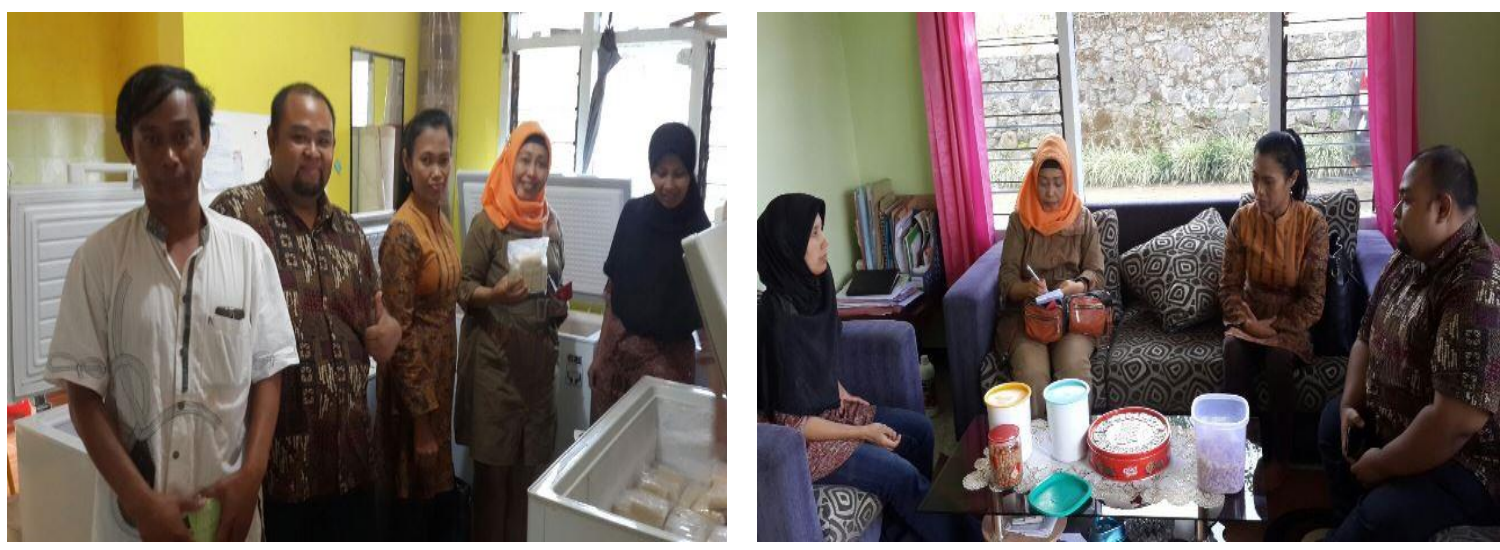

Gambar 5. Monev internal oleh Team UB dan penyerahan freezer di Mitra 2 


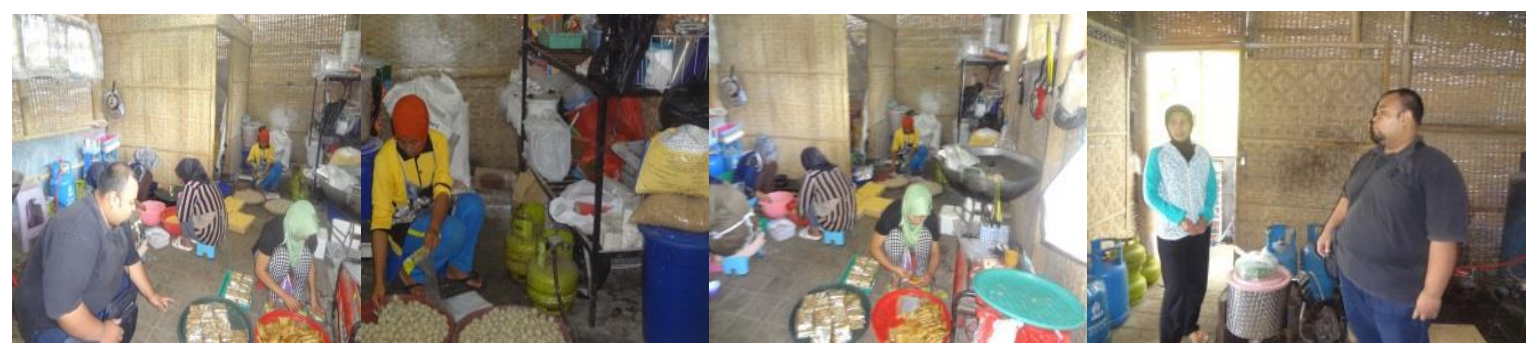

Gambar 6. Sosialisasi Good Manufacturing Practices di Mitra 2.

Tabel 4. Luaran Hasil Kegiatan IbM

\begin{tabular}{|c|c|c|c|}
\hline Luaran & $\begin{array}{c}\text { Sebelum } \\
\text { program IbM }\end{array}$ & Target & $\begin{array}{c}\text { Setelah program } \\
\text { IbM }\end{array}$ \\
\hline $\begin{array}{l}\text { Peningkatan efisiensi pengisian } \\
1000 \text { baglog di Mitra } 1\end{array}$ & 5-8 hari & 100-200 menit & $1-2$ hari \\
\hline $\begin{array}{l}\text { Penerapan Good Agriculture } \\
\text { Practices (GAP) di Mitra 1 } \\
\text { dan Good Manufacturing } \\
\text { Practices di Mitra } 2\end{array}$ & & & $\begin{array}{c}\text { Sudah } \\
\text { dilaksanakan }\end{array}$ \\
\hline $\begin{array}{l}\text { Peningkatan } \\
\text { pengadukan batter di Mitra } 2\end{array}$ & 2 jam & 20 menit & 20 menit \\
\hline $\begin{array}{l}\text { Peningkatan efisiensi } \\
\text { pengadukan tepung dan } \\
\text { penyalutan jamur tiram suwir } \\
\text { di Mitra } 2\end{array}$ & 2 jam & 10 menit & 15 menit \\
\hline $\begin{array}{llll}\text { Produksi } & \text { penyedap } & \text { rasa } & \text { di } \\
\text { Mitra } 2 & & & \end{array}$ & Belum ada & $\begin{array}{l}\text { Produk bubuk, } \\
\text { berwarna putih } \\
\text { kekuningan, } \\
\text { mudah larut, rasa } \\
\text { gurih dan asin }\end{array}$ & $\begin{array}{l}\text { Produk bubuk, } \\
\text { berwarna putih } \\
\text { kekuningan, } \\
\text { mudah larut, rasa } \\
\text { gurih dan asin }\end{array}$ \\
\hline
\end{tabular}

\section{KESIMPULAN}

Dengan adanya alih teknologi mekanis pengisian baglog dengan introduksi mesin pengisi baglog di Mitra 1, terjadi peningkatan efisiensi waktu pengisian baglog. Setelah kegiatan IbM proses persiapan baglog bisa dipercepat menjadi 12 hari. Selain itu, alih teknologi mekanis juga diaplikasikan pada Mitra 2 yaitu dengan introduksi mesin pengaduk adonan, mixer dan penambahan freezer untuk produksi lumpia, risoles, dan keripik jamur tiram. Efisiensi pengadukan tepung dan penyalutan jamur meningkat menjadi 20 menit, sedangkan pengadukan batter meningkat menjadi 15 menit. Sosialisasi dan pendampingan GAP dan GMP juga telah dilaksanakan pada Mitra 1 dan 2.

\section{UCAPAN TERIMAKASIH}

Ucapan terima kasih disampaikan kepada Kementerian Riset, Teknologi, dan Pendidikan Tinggi atas dana Iptek bagi Masyarakat tahun 2015 dan LPPM Universitas Brawijaya yang telah mendukung pelaksanaan kegiatan ini.

\section{DAFTAR PUSTAKA}

Fennema, O.R. 1996. Food Science: A Series of Monograph. Marcel Dekker Inc., New York. 
Fu, H-Y., D-E. Shieh, and C-T. Ho. 2002. Antioxidant and Free Radical Scavenging Activities of Edible Mushrooms. Journal of Food Lipids 9 (1): $35-43$.

Hossain, S, M. Hashimoto, E.K. Choudhury, N. Alam, S.Hussain, M.Hasan, S.K. Choudhury, and I. Mahmud. 2003. Dietary mushroom (Pleurotus ostreatus) ameliorates atherogenic lipid in hypercholesterolaemic rats.
Clinical and Experimental Pharmacology and Physiology 30 (7): 470-475

Kurnianingsih, N. 2008. Khasiat Jamur Tiram. http:// seputarjamurtiram. blog.com. Tanggal akses 26 Februari 2008 . 